\title{
Microleakage on Class V Glass Ionomer Restorations After Cavity Preparation with Aluminum Oxide Air Abrasion
}

\author{
Silmara Aparecida Milori CORONA ${ }^{1}$ \\ Maria Cristina BORSATTO² \\ Renata Andréa Salvitti de Sá ROCHA ${ }^{1}$ \\ Regina Guenka PALMA-DIBB ${ }^{1}$ \\ ${ }^{1}$ Department of Restorative Dentistry and ${ }^{2}$ Department of Pediatric Clinics, Preventive and Social Dentistry, \\ Faculty of Dentistry of Ribeirão Preto, University of São Paulo, Ribeirão Preto, SP, Brazil
}

\begin{abstract}
This in vitro study assessed the marginal microleakage on class $\mathrm{V}$ cavities prepared with aluminum oxide air abrasion and restored with different glass ionomer cements. The cavities were prepared on the buccal and lingual surfaces of 15 sound third molars with an airabrasion device (Kreativ Mach 4.1; New Image) using a 27.5- $\mu \mathrm{m}$ aluminum oxide particle stream, and were assigned to 3 groups of 10 cavities each. The restorative materials were: group I, a conventional glass ionomer cement (Ketac-Fil); groups II and III, resinmodified glass ionomer cements (Vitremer R and Fuji II LC, respectively). After placement of the restorations, the teeth were stored in distilled water at $37^{\circ} \mathrm{C}$ for $24 \mathrm{~h}$, polished and then submitted to a thermocycling regimen of 500 cycles, isolated, immersed in $0.2 \%$ Rhodamine B solution for $24 \mathrm{~h}$, included and serially sectioned. Microleakage was assessed by viewing the specimens under an optical microscope connected to a color video camera and a computer. The images obtained were digitized and analyzed for microleakage using software that allows for a standard quantitative assessment of dye penetration in millimeters. Statistical analysis was done using the Kruskall-Wallis and Wilcoxon tests. Means of dye penetration (\%) were: occlusal - I: $25.76 \pm 34.35$, II: $20.00 \pm 42.16$, III: $28.25 \pm$ 41.67; cervical - I: $23.72 \pm 41.84$; II: $44.22 \pm 49.69$, III: $39.27 \pm 50.74$. No statistically significant differences (p>0.05) were observed among either the glass ionomer cements or the margins. In conclusion, class V cavities restored with either conventional or resinmodified glass ionomer cements after preparation with aluminum oxide air abrasion did not show complete sealing at the enamel and dentin/cementum margins.
\end{abstract}

Key Words: microleakage, air abrasion, glass ionomer cement, cavity preparation.

\section{INTRODUCTION}

Alternative technologies for preparation of conservative cavities have been introduced, such as aluminum oxide air abrasion, first described by Black (1) in 1945. Studies have been developed to assess the behavior of different restorative materials in terms of the marginal sealing of air-abraded cavities (2-4) and bond strength to air-abraded dental substrates (5-11).

The marginal microleakage of resin systems placed in cavities prepared with air abrasion has been investigated. Ferdianakis (3) reported higher marginal leakage and higher gap formation for paste composite resins than for flowable composite resins. Hannig and
Femerling (12), evaluating different composite resins, observed that the combination of air abrasion and adhesives systems resulted, in most cases, in a gap-free adaptation between composites and dentin. Fu and Hannig (13) reported better marginal sealing for lowviscosity polyacid modified composite resins.

SEM investigations $(5,7)$ revealed the presence of macroscopic superficial alterations on the enamel surface after aluminum oxide air abrasion, as well as microscopic irregularities following acid etching. On dentin, some tubules appeared opened when the surface was treated for $5 \mathrm{~s}$, while applications longer than $5 \mathrm{~s}$ led to the obstruction of the dentinal tubules, possibly due to an increase of the residual dust layer (14). 
Treatment of the dentin surface with polyacrylic acid before the placement of glass ionomer restorative systems removes the smear layer, without causing dentin demineralization or removal of the smear plugs, thus maintaining calcium ions available for the chemical reaction with the cement, and avoiding contamination of the restorative material with humidity from dentinal fluid (15).

The literature is scarce on studies investigating whether the use of air abrasion for cavity preparation would affect the marginal sealing of glass ionomer cement restorations. Therefore, the purpose of this study was to assess the degree of marginal microleakage on class $\mathrm{V}$ cavities prepared with an aluminum oxide air-abrasion device and restored with one conventional and two resin-modified glass ionomer cements.

\section{MATERIAL AND METHODS}

Fifteen sound human third molars, extracted within a six-month period and stored in saline at $4^{\circ} \mathrm{C}$, were selected and cleaned with water/pumice slurry in rubber prophylaxis cups.

Thirty class V cavities, with the occlusal margin in enamel and the cervical margin located $1 \mathrm{~mm}$ below the amelocemental junction, were prepared on buccal and lingual surfaces. Cavity dimensions were standardized using a template to trace onto both surfaces an outline with $3 \mathrm{~mm}$ of mesiodistal width and $3 \mathrm{~mm}$ of occlusogingival length. The depth of the cavities was approximately $1.5 \mathrm{~mm}$, calibrated with a premarked periodontal probe.

Three groups of ten cavities each were formed at random. Cavities were prepared with the handpiece of Kreativ Mach 4.1 air-abrasive system (New Image, São Paulo, SP, Brazil), with a 0.011-inch nozzle opening, using a $27.5-\mu \mathrm{m}$ aluminum oxide particle stream at 60 psi air pressure, with $7 \mathrm{~g} / \mathrm{min}$ intensity on enamel and 4 $\mathrm{g} / \mathrm{min}$ on dentin. The aluminum oxide jet was delivered at a distance of approximately $2 \mathrm{~mm}$ and at a $45^{\circ}$ angle to the occlusal surface.

Cavities were restored with three glass ionomer cements: group I, a conventional glass ionomer cement (Ketac Fil, 3M/ESPE, Seefeld, Germany); groups II and III, resin-modified glass ionomer cements (Vitremer R, 3M Dental Products, St Paul, MN, USA and Fuji II LC, GC Co., Tokyo, Japan, respectively). In a same tooth, buccal and lingual cavities were restored with different materials.

After preparation of cavities, groups I and III received surface treatment with a $40 \%$ polyacrylic acid (Durelon, 3M/ESPE), applied to enamel and dentin with light scrubbing motion for $10 \mathrm{~s}$. The cavities were rinsed for $20 \mathrm{~s}$ and gently dried with absorbent paper to keep the tooth surface moist. The surface treatment for group II consisted of the application and light curing of the primer supplied in the material kit, according to manufacturer instructions. Afterwards, standard powder/liquid ratio of the restorative systems was dispensed and mixed as specified by the manufacturers. The resulting mixtures were injected into the cavities in a single increment using a Centrix injector to prevent voids and bubble formation.

In group I, the restorative system was chemically activated within a compulsory setting time. In groups II and III, the materials were light-cured as specified by the manufacturers using a visible light-curing unit with a $450 \mathrm{~mW} / \mathrm{cm}^{2}$ output (XL3000, 3M Dental Products, St. Paul, MN, USA). In groups I and III, the glass ionomer surface was protected by a thin layer of cavity varnish (Cavitine, SS White, Rio de Janeiro, RJ, Brazil), while in group II the surface was coated with Vitremer finishing gloss (3M Dental Products).

The specimens were stored in distilled water at $37^{\circ} \mathrm{C}$ for $24 \mathrm{~h}$ and the restorations were polished with Super-Snap discs (Shofu Inc., Kyoto, Japan). The teeth were subjected to a thermocycling regimen of 500 cycles between $5^{\circ} \mathrm{C}$ and $55^{\circ} \mathrm{C}$. Dwell time was $1 \mathrm{~min}$ with a 3 -second transfer time between baths.

In preparation for the dye penetration test, the specimens were superficially dried, entirely sealed (including apical region) with epoxy resin and two coats of nail varnish (only a $2-\mathrm{mm}$ window around the cavity margins was left exposed) and immersed in a $0.2 \%$ Rhodamine B solution for $24 \mathrm{~h}$. Afterwards, the surface-adhered dye was rinsed in tap water and the epoxy resin and nail varnish were removed with a sharp instrument. The teeth were embedded in chemically activated acrylic resin (JET, Clássico, São Paulo, SP, Brazil) and bisected longitudinally in a mesiodistal direction with the water-cooled diamond saw of a sectioning machine (Minitom, Struers A/S, Copenhagen, Denmark). The separate buccal and lingual halves were embedded again in acrylic resin blocks and sectioned in a buccolingual direction, providing two to three 1-mm thick cuts per tooth. This approach was done because 
the third molar's accentuated convexity did not enable the buccal and lingual cavities to be accurately centralized and therefore would not allow for both restorations to be sectioned in the same slice.

The cuts were initially thinned in a polishing machine (Politriz, Struers A/S) using \#180- to \#600grit wet silicon carbide papers and then manually smoothed with \#1000- and \#1200-grit wet silicon carbide papers to obtain a flat surface and an average final thickness of $0.25 \mathrm{~mm}$.

The sections were identified, fixed on microscope slides and examined for leakage separately, by viewing them under a X2.5 magnification optical microscope (Axioskope, Zeiss, Jena, Germany) connected to a color video camera (TK-1270, JVC, Tokyo, Japan). The images obtained were transmitted to a personal computer and after digitization they were analyzed using the KS300-v2.0 software (Kontron Elektronik, GmbH, Eching bei München, Germany), which allows for a standard quantitative assessment of microleakage in millimeters.

The depth of the cavities and the extension of dye penetration along the occlusal and cervical margins towards the axial wall were determined and the percentage of infiltration was calculated.

Data were analyzed statistically using the Kruskal-Wallis and Wilcoxon tests.

\section{RESULTS}

The means of dye penetration are given in Table 1 . Statistically significant differences were not observed ( $>0.05$ ) among either the margins (occlusal and dentin/ cementum) or the materials, even though the conventional glass ionomer cement (Ketac Fil) had numerically lesser dye penetration than the resin-modified glass ionomer cements (Vitremer R and Fuji II LC).

Table 1. Means (\%) and standard deviation of dye penetration at enamel and dentin/cementum margins.

\begin{tabular}{lrrr}
\hline & Ketac Fil & Vitremer R & Fuji II LC \\
\hline Enamel & 25.76 & 20.00 & 28.25 \\
& \pm 34.35 & \pm 42.16 & \pm 41.67 \\
& & & \\
Dentin/Cementum & 23.72 & 44.22 & 39.27 \\
& \pm 41.84 & \pm 49.69 & \pm 50.74 \\
\hline
\end{tabular}

\section{DISCUSSION}

The findings of this study cannot be compared to those of other studies due to the lack of available data from research using similar methodology.

We observed that glass ionomer cements used as restorative materials in cavities prepared with aluminum oxide air abrasion had similar behavior. None of the materials provided complete sealing at enamel or dentin/cementum margins. Although there were no significant differences among the materials, the conventional glass ionomer cement had the numerically lowest means of dye penetration, particularly at dentin/ cementum margins. Likewise, the enamel margin had numerically lower means of dye penetration, even though no statistically significant difference was detected between occlusal and cervical margins.

The results of this study can possibly be attributed to the fact that application of aluminum oxide air abrasion produces macroscopically visible irregularities on the tooth surface, which may interfere with the intimate contact between the restorative material and the cavity walls. This might impair the adaptation of the material and facilitate the formation of internal voids, even when a Centrix syringe is used for insertion.

Several studies $(5,16,17)$ showed that the association of aluminum oxide air abrasion and phosphoric acid etching produced a surface appearance on enamel similar to that obtained with acid etching alone. Other authors $(14,18)$ investigating the association of these techniques on dentin observed the formation of cracks and the existence of open dentin tubules. However, the findings of the present study suggest that the action of weak acids, i.e., polyacrylic acid, or primers on airabraded dentin is unable to completely remove the smear layer, leaving the dentinal tubules obliterated with smear plugs. This allows for the desirable chemical interaction between the carboxylic groups from the glass ionomer cements and calcium ions from the dental substrate.

Studies $(19,20)$ assessing the marginal microleakage in cavities prepared with high-speed burs and restored with conventional and resin-modified glass ionomer cements reached similar results for both types of glass ionomer restorations.

Further research should be carried out with different restorative materials to investigate which are capable of completely sealing the margins of air-abraded 
cavities.

In conclusion, class $\mathrm{V}$ cavities restored with either conventional or resin-modified glass ionomer cements after preparation with an aluminum oxide airabrasion device did not show complete sealing at the enamel and dentin/cementum margins.

\section{RESUMO}

Este estudo in vitro avaliou a microinfiltração marginal em cavidades classe $\mathrm{V}$ preparadas com jato de óxido de alumínio e restauradas com diferentes sistemas ionôméricos. As cavidades foram preparadas nas superfícies vestibular e lingual de 15 terceiros molares hígidos e foram divididas em três grupos com 10 cavidades cada um. Os seguintes materiais foram utilizados: no grupo I, cimento de ionômero de vidro convencional (Ketac Fil) e nos grupo II e III, cimentos de ionômero de vidro modificado por monômeros resinosos (Vitremer e Fuji II LC, respectivamente). O preparo cavitário foi realizado por meio da aplicação do jato de óxido de alumínio (Kreativ Mach 4.1; New Image), com partículas de $27,5 \mu \mathrm{m}$. Após a restauração das cavidades, os dentes foram armazenados durante $24 \mathrm{~h}$ em água destilada a $37^{\circ} \mathrm{C}$, polidos e então submetido a termociclagem ( 500 ciclos), imersos em Rodamina B a $0,2 \%$ por 24 h, incluídos e seccionados. A análise da microinfiltração marginal foi realizada por meio de um microscópio óptico acoplado a uma câmera e a um computador. As imagens obtidas foram digitalizadas e analisadas utilizando um software que permite uma análise quantitativa padronizada da microinfiltração, em milímetros. As médias (\%) obtidas foram: oclusal - I: $25,76 \pm 34,35$; II: 20,00 \pm 42,16; III: $28,25 \pm 41,67$; cervical I: $23,72 \pm 41,84$; II: 44,22 \pm 49,69; III: $39,27 \pm 50,74$. Os dados foram submetidos à análise estatística, utilizando os testes de Kruskall-Wallis e Wilcoxon. Não houve diferença estatisticamente significante $(p>0.05)$ entre os materiais testados nem entre as margens oclusal e cervical. Conclui-se que em cavidades classe $\mathrm{V}$ preparadas com ar abrasão e restauradas com cimentos de ionômero de vidro convencional e modificados por monômeros resinosos não houve completo vedamento marginal.

\section{ACKNOWLEDGEMENTS}

The authors are grateful to FAPESP (Fundação de Amparo à Pesquisa do Estado de São Paulo) for financial support (Scientific Initiation fellowship - grant number: 01/05422-3).

\section{REFERENCES}

1. Black R. Technique for non-mechanical preparation of cavities and prophylaxis. J Am Dent Assoc 1945;32:955-965.
2. Christensen GJ. Cavity preparation: cutting or abrasion? J Am Dent Assoc 1996;127:1651-1654.

3. Ferdianakis K. Microleakage reduction from newer esthetic restorative materials in permanent molars. J Clin Pediatr Dent 1998;22:221-229.

4. Guirguis R, Lee J, Conry J. Microleakage of restorations prepared with air abrasion. Pediatr Dent 1999;21:311-315.

5. Ellis RW, Latta MA, Westerman GH. Effect of air abrasion and acid etching on sealant retention: an in vitro study. Pediatr Dent 1999;21:316-319.

6. Hatibovic-Kofman S, Wright GZ, Braverman I. Microleakage of sealants after conventional, bur and air-abrasion preparation of pits and fissures. Pediatr Dent 1998;20:173-176.

7. Nikaido T, Kataumi M, Burrow M, Inokoshi S, Yamada T, Takatsu $T$. Bond strengths of resin to enamel and dentin treated with low-pressure air abrasion. Oper Dent 1996;21:218-224.

8. Rinaudo PJ, Cochran MA, Moore BK. The effect of air abrasion on shear bond strength to dentin with dental adhesives. Oper Dent 1997;22:254-259.

9. Roeder LB, Berry AE, You C, Powers JM. Bond strength of composite to air-abraded enamel and dentin. Oper Dent 1995;20:186-190.

10. Saraceni CHC. Resistência à tração de um sistema adesivo em superfícies dentinárias tratadas com microabrasão por óxido de alumínio e irradiação com laser de Er:YAG. [Master's thesis]. São Paulo: Faculdade de Odontologia de São Paulo, Universidade de São Paulo; 1998.114 p.

11. Silva PCG. Avaliação "in vitro" da resistência à tração em esmalte e dentina submetidos a ação do jato de óxido de alumínio. [Master's thesis]. Ribeirão Preto: Faculdade de Odontologia de Ribeirão Preto, Universidade de São Paulo; 2001. 99 p.

12. Hannig M, Femerling T. Influence of air abrasion treatment on the interfacial bond between composite and dentin. Oper Dent 1998;23:258-265.

13. Fu B, Hannig M. Effects of air abrasion and acid etching on the microleakage of preventive Class I resin restorations: an in vitro study. J Esthet Dent 1999;11:143-148.

14. Bester RB, De Wet FA, Nel JC. The effect of airborne particle abrasion on the dentin smear layer and dentin: an in vitro investigation. Int J Prosthodont 1995;8:46-50.

15. Powis DR, Folleras T, Merson SA, Wilson AD. Improved adhesion of a glass ionomer cement to dentine and enamel. J Dent Res 1982;61:1416-1422.

16. Dotty WD, Pettey D, Holder R, Phillips S. KCP 2000 enamel etching abilities tested. J Dent Res 1994;73:411.

17. Katora ME, Jubachi T, Polimus MM. Air-abrasive etching of enamel surface. Quintessence Int 1981;12:967-968.

18. Gwinnet AJ, Berry EA. Morphological characteristics of enamel and dentin prepared with air abrasion. J Dent Res 1996;75:127.

19. Brackett WW, Gunnin TD, Johnson WW, Conkin JE. Microleakage of light-cured glass-ionomer restorative materials. Quintessence Int 1995;26:583-585.

20. De Magalhães CS, Serra MC, Rodrigues Jr AL. Volumetric microleakage assessment of glass-ionomer-resin composite hybrid materials. Quintessence Int 1999;30:117-121.

Accepted February 5, 2003 